\title{
Resenha
}

\section{Diálogos na perspectiva histórico-cultural: interlocuções com a clínica da atividade}

\author{
Review Cultural-historical dialogs in the perspective: \\ interlocutions with the clinic of the activity
}

\author{
Reseña Diálogos en la perspectiva histórico-cultural: \\ interlocuciones con la clínica de la actividad
}

\author{
Airton Pereira do Rêgo Barros \\ Universidade Federal de Uberlândia - Uberlândia - MG - Brasil
}

Banks-Leite, L.; Smolka, A. L. B.; Anjos, D. D. (Orgs.) (2016). Diálogos na perspectiva históricocultural: interlocuções com a clínica da atividade. Campinas: Mercado de Letras, 306 p.

A obra da qual trata esta resenha faz uma excelente articulação entre as bases conceituais e teóricas que sustentam a perspectiva histórico-cultural em Psicologia e algumas pesquisas realizadas à luz da clínica da atividade (CA), que analisam as relações de trabalhado a partir da ótica dos trabalhadores, focando-se em suas atividades, modos de agir e fazer.

A coletânea de textos em questão teve sua origem no seminário Vygotsky: teoria e método - perspectivas em debate, realizado em 2013 na Faculdade de Educação da Unicamp e organizado pelo Grupo de Pesquisa em Pensamento em Linguagem (GPPL). As seções temáticas desenvolvidas na obra se baseiam no referencial teórico da CA, concebido por Yves Clot, professor titular de psicologia do trabalho do Conservatoire National dês Arts et Métiers (CNAM) de Paris.

As seções temáticas estão divididas em duas partes: a primeira destinada as Questões do desenvolvimento humano e a segunda sobre Estudos em clínica da atividade. Os dois primeiros capítulos versam sobre a noção de desenvolvimento humano e o estatuto dos instrumentos técnicos e semióticos. O primeiro texto traz a relevo a importância das duas teses elementares de Vygotski para a compreensão do desenvolvimento humano: a de que a especificidade humana é de natureza cultural, assim como são de origem social as funções humanas. Sendo assim, a atividade humana inexoravelmente exige uma passagem dos meios naturais para os simbólicos, ou seja, o encontro das funções biológicas e culturais se dá através do simbólico, da linguagem. $O$ segundo capítulo ressalta que a atividade humana depende dos instrumentos criados pela cultura, e analisa o processo de desenvolvimento humano por meio da apropriação do instrumento de trabalho numa situação prototípica. Nesse texto a autora coloca em relevo a ideia de que os instrumentos são constituídos por duas partes: uma objetiva, natural e externa ao sujeito e outra parte subjetiva, psicológica e interna; assim, o instrumento é visto pelo sujeito como uma extensão do seu próprio corpo. Desta forma, a apropriação do instrumento se dá por meio de um movimento gradual que vai do exterior ao interior. A análise da situação prototípica observada demonstra que as contingências surgidas com a realização da tarefa exigem uma adaptação dos gestos do sujeito em sua relação com o instrumento de trabalho. 
No terceiro capítulo, o autor afirma que a situação prototípica analisada no texto anterior revelou-se um bloqueio no desenvolvimento do trabalho causado pelo dispositivo da formação. Bloqueio estabelecido pelo poder da prescrição (instrução oficial) sobre o modo de fazer genérico, mesmo diante da ineficiência da prescrição, o que vai contra a concepção de Vygotski de que o humano é o sujeito do seu comportamento. "O desenvolvimento humano é um fenômeno com direções potencialmente infinitas, sendo o desenvolvimento realizado apenas um dos resultados no campo de batalha entre a sociedade e o psiquismo". O desenvolvimento tem implicações em termos de poder e é denso historicamente, dessa forma, o agir humano deve ser visto sempre a partir de uma sociedade.

A primeira parte da obra é encerrada com três capítulos que têm como eixo temático a questão da afetividade e das emoções e sua influência no desenvolvimento humano. O escrito traz a contribuição de pensadores de diferentes áreas do conhecimento, como: Rimé, Wallon, Damásio e o próprio Clot, como também demonstra a influência de Espinoza na concepção de Vygotski sobre a dimensão afetiva do desenvolvimento humano, pois ambos tentam superar a dicotomia entre os aspectos representacional e biológico envolvidos nas questões emocionais humanas, enfatizando a influência dos processos sociais perversos na origem do sofrimento humano. O capítulo seguinte, escrito por Clot, fala sobre a interfuncionalidade dos afetos, emoções e sentimentos. O autor, neste capítulo, faz uma diferenciação entre os afetos e as emoções, assim como deixa claro que, apesar das emoções estarem subordinadas a dimensão corporal, seus significados dependem de um modo compartilhado de representar a experiência. Já os afetos, para Clot, de acordo com Espinoza, têm uma relação direta com a ação, aumentando ou diminuindo seu poder. Já o último capítulo desta parte da obra ressalta que enquanto Wallon e Vygotski se preocupam em explicar a gênese e a função das emoções no desenvolvimento humano, Clot busca explicar a dinâmica e o desenvolvimento da atividade; dessa forma, as ideias desses autores interagem de forma complementar.

A segunda parte do livro que aborda especificamente a clínica da atividade (CA) é introduzida por três capítulos que se interrogam sobre quem são os verdadeiros protagonistas das transformações no campo do trabalho: o expert (especialista), o intervenant (interventor) ou os próprios profissionais do oficio? Tal questão traz consigo muitas outras que dizem respeito à relação entre intervenção e pesquisa. Para resolvê-las os autores dos textos enfocados aqui e a debatedora Cláudia Osório concordam que "o transformar precede o conhecer" e que as funções do especialista e do clínico são muito distintas, haja vista que para o segundo o trabalhador é o protagonista das transformações. Más existem pontos de discordância entre a debatedora, e algumas ideias apresentadas no capítulo escrito por Angero e Lima, sobretudo no que se refere à questão metodológica "a pesquisa começa quando a intervenção termina". A debatedora tampouco concorda com a separação entre os objetivos da pesquisa e os da intervenção, pois isso seria uma decisão artificial, considerando que pesquisa e intervenção constituem fonte e recurso uma para a outra, sendo impossível separá-las no tempo.

A partir de então o livro passa a abordar o tema da autoconfrontação, procedimento elaborado por Daniel Faïta, como método da CA por excelência. Primeiramente, uma seção de três capítulos trata o tema da autoconfrontação como método utilizado em dois estudos: o primeiro analisa situações relacionadas a um projeto de formação de professores do ensino fundamental I e o segundo envolveu professores de língua francesa em um programa de formação continuada. Essas pesquisas foram comentadas em um terceiro texto, onde a autora se questiona sobre o que as autoconfrontações simples e cruzada podem dizer acerca do trabalho do professor? Souza-e-Silva conduz seu debate a partir do Interacionismo Sociodiscursivo (ISD), que serviu de base para os estudos citados. A análise identificou os parâmetros na produção de marcas linguísticas e o efeito de sentido que decorre delas, desta forma, a autora reforça que a autoconfrontação se constitui em um espaço de transformação dos atores sociais.

Nos três capítulos que compõem a última seção do livro, o tema principal segue sendo a utilização da autoconfrontação como método de pesquisa e intervenção no contexto da CA. O primeiro texto dessa seção traz uma pesquisa realizada com funcionários de um banco estatal com altos índices de absenteísmo. Nesta pesquisa, os métodos da autoconfrontação serviram para os profissionais perceberem que as atividades impedidas e não realizadas, assim como certos conteúdos latentes na situação de trabalho exerciam um papel importante na saúde psicológica dos trabalhadores e na forma em como eles significavamas próprias ações. Na sequência, é apresentada uma pesquisa realizada com duas professoras dos anos iniciais do ensino fundamental, que precisavam lidar com a questão da heterogeneidade dos saberes das crianças em sala de aula. Ambas precisavam revisar suas atividades de trabalho, pois a diversidade no nível de aprendizado dos alunos constituía um desafio e exigia uma mudança nas práticas pedagógicas.

Nas pesquisas citadas, os profissionais são inicialmente convidados a assistir a filmagem de suas atividades de trabalho, primeiramente acompanhados apenas do pesquisador (Autoconfrontação Simples), posteriormente ao lado de um companheiro de trabalho (Autoconfrontação Cruzada). Nos dois casos eles devem debater sobre o que assistiram. Por fim, o procedimento acaba em um encontro com o coletivo, onde vários companheiros de atividade devem debater sobre as possibilidades de suas ações no ambiente de trabalho, pois de acordo com esta perspectiva as transformações se efetivam e são sustentadas pela coletividade. Finalmente, o último capítulo do livro discute a importância das verbalizações propiciadas pelas autoconfrontações como forma de transformar as ações de trabalho a partir das reflexões e da ressignificação dessas atividades. Trata-se, nesse caso, do papel de transformador exercido pela linguagematravés das verbalizações dos trabalhadores.

Sendo assim, a obra em questão é uma excelente oportunidade para entendermos como os referenciais teóricos 
e metodológicos da CA estão inseridos no campo da vertente histórico-cultural em psicologia e como a filosofia Marxista, a través do conceito de materialismo histórico-dialético, influen- cia profundamente a maneira como a clínica da atividade interpreta as ações e relações de poder no contexto do trabalho.

Recebido em: 04/12/2015

Reformulado em: 12/07/2016

Aprovado em: 14/07/2016

\section{Sobre o autor}

Airton Pereira do Rêgo Barros (airton.barros@ufu.br)

Doutor em Psicologia Social pela Universidade de Valência, Espanha. Professor do Instituto de Psicologia (IPUFU) da Universidade de Uberlândia - MG 